\title{
Gothic Spaces and the Tropical City: reading The Crocodile Fury, Haunting the Tiger, Life's Mysteries
}

\author{
Sathyabhama Daly
}

James Cook University, Australia

\begin{abstract}
Beth Yahp's The Crocodile Fury (1992), K.S. Maniam's Haunting the Tiger (1996), and Shirley Lim's Life's Mysteries (1995) articulate the ambivalence of interpreting the cultural beliefs of the Malays, Chinese, and Indians of the former Malaya with the evolving spiritual beliefs of Christianity and Catholicism influenced by British colonisation. In Beth Yahp's The Crocodile Fury the ghosts of the colonial past vie for power with the demons of Chinese cultural beliefs in a convent situated in the liminal space between the jungle and the urban environment. The convent is a "civilised space" with the jungle as an encroaching wilderness haunted by Chinese gods and the female vampire ghost Pontianak of the Malay cultural tradition. Similarly, Maniam's short stories in Haunting the Tiger situate the supernatural and the abject in the liminal spaces between the city and the jungle to express the metaphorical exile experienced by the Indian and Chinese diaspora in Malaysia. The trope of liminality is most evident in Shirley Lim's short stories in Life's Mysteries where the domestic and urban space of culture are viewed through prisms of imprisonment and disempowerment. The authors uncover the psychological and social exile experienced by colonised subjects through the gothic themes of shadows, darkness and the underworld.
\end{abstract}

$\mathrm{G}$ othic fiction with its haunted spaces, ghosts and underworld themes of alienated characters in search of a coherent identity emerged in the Western literary canon in the late eighteenth and early nineteenth-century. Since then Gothic fiction continues to be used by writers to explore philosophical, social and psychological anxieties of being in the world. In The Cambridge Companion to Gothic Fiction, Hogle suggests "Gothic fictions generally play with and oscillate between the earthly laws of conventional reality and the possibilities of the supernatural" (2002, p. 
2). This paper on Gothic Spaces and the tropical city as read through Yahp's The Crocodile Fury (1992), Maniam's Haunting the Tiger (1996), and Lim's Life's Mysteries (1995), suggests these authors play with the South-East Asian cultural narratives of ghosts and haunted spaces to articulate the impact of colonisation on the shared history of the Malays, Chinese and Indians of the former Malaya - now contemporary Malaysia and Singapore. In Gothic fiction, the setting is often a haunted space, be it an antiquated mansion, a prison, a graveyard or "urban underworld" (Hogle, 2002, p. 2). Yahp (1992), Maniam (1996), and Lim (1995) set their stories in civilised urban spaces-an institution, a convent, or a city-with the jungle and its verdant tropical growth symbolising chaos and growth. Their use of haunted settings evokes the alienation and the repressed history of the marginalised characters in their stories.

The Gothic trope of haunted spaces and conflicting religious beliefs is most evident in The Crocodile Fury (Yahp, 1992) where ghosts of the colonial past and demons and spectres of Chinese cultural beliefs vie for power in the urban space of a convent, situated at the edge of the jungle. The convent is a "civilised space" with the jungle as an encroaching wilderness haunted by ghosts, demons, and the female vampire ghost or Pontianak of the Malay cultural tradition. The narrator is a sceptical student interrogating the animistic beliefs of her Siamese-Chinese cultural heritage and the monotheistic beliefs of the nuns and their influence in shaping her identity. In Haunting the Tiger (1996), Maniam juxtaposes the animistic space of the jungle with the cold, sterile environment of the city and zombie characters to voice the metaphorical exile colonised subjects experience in their own country of birth. Similarly, in Life's Mysteries (1995) Lim's abject characters are haunted by memories of home, relationships and cultural rituals that have lost their significance in creating a sense of belonging to a community or a society. Yahp, Maniam and Lim manipulate the supernatural elements inherent in South-East Asian cultural beliefs to articulate the silences and repressions of postcolonial societies. Their use of haunted spaces and gothic themes supports Freud's premise of "the unconscious as a deep repository of very old, infantile, and repressed memories or impulses, the archaic underworld of the self" (cited in Hogle, 2002 , p. 3). These writers use the literary trope of the Gothic to explore social, psychological and cultural anxieties of postcolonial subjectivity. As Andrew Hock-Soon $\mathrm{Ng}$ suggests "the Gothic-with its emphases on liminality, ambiguity, ghosts, transgressions and taboos-proves most useful as an aesthetic tool to illuminate the palimpsests that become 'repressed' in the process of writing the nation" (2006, pp.7576).

In The Crocodile Fury (1992), the convent is the site of struggle between ghosts of the colonial past and the supernatural folklore of the Malay, Chinese and Indians. The convent functions as a symbol of colonial power imposing a rational, 'superior' discourse on the superstitious beliefs of the local population. The power nexus between the coloniser and the colonised is presented through the stories of the lover 
and rich man, the grandmother, the mother, and the bully. The lover is characterised as an beautiful otherworldly native woman. Her white skin, haunting eyes and entrapment within the basement of the mansion contain metaphors of the Selkie myth of Gaelic folklore. As Peter Couteur in "Slipping off the Sealskin: Gender, Species, and Fictive Kinship in Selkie Folktales" suggests, "The Seal Wife is, of course, an explicitly gendered and sexualised tale; the male captures the female against her will, coercing her into sexual, domestic and childbearing roles" (2015, p.7). In The Crocodile Fury, the lover is imprisoned within the confines of the house, the bedroom of which is set in the basement: "When the rich man wrapped his underwater arms around her he discovered a scaly ridge over her backbone.... The sea entering his body chilled him to the bone" (Yahp, 1992, p. 143). The lover is also depicted as the vampire ghost, the Pontianak, who lures men to their destruction:

Some say they see the saddest and most beautiful face, the face of the Virgin, the face of a queen. Others see a burned hag's face, fire-licked to leather, with its lips stretched wide as it leaps from the moonlight with a deafening howl. Others say they see in moonlight only the billowing hair and skin like the underbelly of a fish: there is no face. (Yahp, 1992, p. 48)

In the intricacies of these depictions, the ambivalent power nexus between the native female lover and the rich man suggests that power cannot be simplified by the dichotomy of coloniser and colonised.

The history of colonisation is presented through the story of the rich man who builds a mansion on a hill, surrounded by the jungle. The antiquated mansion peopled by ghosts becomes a convent in the newly emerging urban space of the capital city:

In those days the convent ghosthouse was already famous throughout the city. Convent days were famous for their occasional bangings, cacklings and screechings, convent nights for books flying from their shelves in neat order, troops of see-through soldiers patrolling the halls. Bandit shadows slumped in unlikely corners, pointing to wounds that bled no more. Convent afternoons spied an occasional sad woman in shimmering white, pausing for an instant at the top of the stairs. When convent girls ran screaming the nuns cried 'Nonsense!' and set them Hail Marys for overactive imaginations, litter duty for playing tricks (Yahp, 1992, p. 32)

The narrator interrogates the Siamese-Chinese cultural beliefs of the grandmother, as well as the conversion to Christianity of the mother, who works in the laundry at the convent. The conflict between Asian and European ways of interpreting the world is 
presented through the grandmother's story and the challenges the nuns experience eradicating the heathen beliefs of the local children.

In the novel, the grandmother is a repository of Siamese-Chinese cultural traditions. Her narrative is of powerlessness and abuse as a girl child born into poverty: "When I was a young girl I was brought to live in a house on a hill. I was bonded to the house as a servant because my family had too many girls" (Yahp, 1992, p. 133). In the rich man's mansion, her status is as the exotic other, a pubescent child dancing to the demands of the rich man and his guests: "She jumped and spun till the rich man signalled her to stop. Her face ran in sweat streaks, her skin glinted brown through the powdery mask" (Yahp, 1992, p. 49). Her privileged status in the rich man's house creates jealousy and distrust among the other servants, who punish her with beatings when the rich man is away. However, the gothic narrative of female disempowerment is subverted through the metaphor of the grandmother's "extra eye." Her destiny is depicted as a quirk of fate when a beating she receives from the cook results in the opening of her "extra eye." The grandmother's extra eye, which she believes has been gifted by her ancestors to accumulate wealth and status, is the mediator between the real world and the world of the supernatural:

This was my grandmother's easy time, her young woman's time, every day not filled with ducking and scowling but with discovery; charms cleverly cajoled from wisewomen and ghostchasers, the whys and wherefores of ghosts, gods and demons painstakingly learnt by heart. (Yahp, 1992, p. 96)

The Chinese community seek her knowledge to appease ancestors and ghosts with offerings of food, joss sticks and prayers. The time of plenty wanes as the grandmother ages. She loses her supernatural vision when a bandit hits the region of her "extra eye" with the butt of a rifle. She becomes an aged Chinese woman intent on passing on her cultural knowledge to the narrator and the bully.

Marginalisation and powerlessness also stamp the mother's life story in The Crocodile Fury (1992). As a girl child, she is sold to a brothel-keeper, because her parents cannot afford to feed and educate her. Her destitute life changes when she is adopted by the grandmother to assist in her "ghost catching" rituals. When she has an illegitimate child, the grandmother sends her to the convent to be cared for by the nuns. The convent functions as a place of Christian charity as well as a colonial metaphor for the mother's conversion to Christianity: "Before my mother became a Christian she was convinced the badluck was a winged demon crouching on her back" (Yahp, 1992, p. 227). The Catholic themes of sin, retribution and penance form the basis of the mother's life story. Her faith is reinforced when the nuns attribute her visions of the Virgin Mary and saints as evidence Christianity has saved her soul, whereas the 
grandmother's prayers and ghost-appeasing rituals are condemned as heathen beliefs requiring exorcism and penance. The grandmother's animistic beliefs are that ghosts and demons can be appeased through charms, offerings and prayers and that life has to be endured:

Unlike the nuns Grandmother says there is no one track that everyone must follow. Everything moves in a pattern of dips and rises, goodluck curves, treacherous folds. Everything has a place. Good or bad, wherever the pattern takes you, there you will go. (Yahp, 1992, p. 55)

The mother's Christian belief in obedience, penance, and the "promised peace of heaven" conflicts with the grandmother's beliefs in Chinese gods and demons (Yahp, 1992 , p. 265). Their differing religious beliefs result in the grandmother passing on her cultural traditions to the narrator and the bully. She instructs them to take photographs of the haunted spaces of the convent and the activities of the nuns to undermine their authority.

It is evident the narrator and the bully negotiate a contested space of conflicting religious traditions. Their playfulness in setting up haunted spaces with white sheets, darkened rooms and trick photography suggests they do not believe in the supernatural, but respect the grandmother's influence in shaping their cultural identity:

Grandmother wants her seeing to be written in shapes and patterns she herself can't read. In the words she sent both my mother and me to the convent to learn, the words of newspapers and city records, not those of talking-story or ghostchasing, or charm. That is a part of Grandmother's plan: to learn the word shapes and patterns of the nuns so her seeing can be printed on golden-edged paper and bound between covers of shiny red leather, and kept in a glass case at night and taken out in the daytime to be read and copied and sung from, and taught to little children by heart. (Yahp, 1992, pp.192-193).

The grandmother's insistence on documenting cultural traditions and interrogating religious beliefs whereby Christianity is not the only truth implies: "That there's more than their way of seeing, and more to life and afterlife than dressing in white with a head wrapped in cloth, and making everyone read their book, and always falling on their knees, praying" (Yahp, 1992, p. 193). The interrogation of Chinese cultural beliefs and Catholicism suggest there are multiple truths and that differing cultural beliefs can be assimilated.

While The Crocodile Fury (Yahp, 1992) is about the superimposition of Christian belief systems on an evolving Malaysian identity, Maniam's short stories in Haunting the 
Tiger (1996) examine the impact of colonisation on the Indians and Chinese who went to Malaya as indentured labourers or immigrants in search of economic wealth. Many of the stories portray abject, liminal characters seeking a coherent cultural identity, but whose desires are never realised because of their adherences to religious traditions which no longer serve them, or the social and cultural constraints imposed on them by the society they live in. In his short story "Terminal," Maniam's use of the Gothic trope of zombie characters ${ }^{1}$, blood rituals, and haunted spaces support Hogle's premise that Gothic narratives allow writers and readers to confront "newly ascendant cultural and psychological contradictions and still provide us with a recurring method for shaping and obscuring our fears and forbidden desires" (2002, p. 6). The Gothic elements in "Terminal" and "Haunting the Tiger" (Maniam, 1996) are a literary strategy to articulate the alienation and the displacement felt by migrants - the condition of "not being home" in an environment that privileges one race over the other races that forged the Malaysian identity.

In "Terminal," Maniam intensifies the Dracula narrative of unreal people and othered beings who seek to define themselves in a society increasingly intolerant of their cultural values and traditions. The narrator's marginalised status is presented through his distrust of the city and its nameless, faceless crowd. The city itself is depicted as a hostile structure of glass and steel compared to the rural haven of trees and space:

City existence had driven me into a mild depression. I couldn't stand the traffic jams, the constant criss-crossing of light that filled the streets between those flashy buildings and the impersonal crowds at the shopping centres. I must have inherited my grandfather's love for a quiet life lived off the land. (Maniam, 1996, p. 1)

The narrator uses the binary of city and country to hint at the undercurrents of racial disharmony that threaten the multicultural society. The disjunction between the narrator and his friend Kok Seng, a successful Chinese business man, is characterised by the narrator's affinity with nature, whilst Kok Seng prefers the air-conditioned freeze of "glass-sheathed buildings" and "The Tower, that much-praised icon of progress and technological achievement" (Maniam, 1996, p.1).

As the story progresses, Kok Seng becomes increasingly disillusioned with the wealth and entrenched corruption of the city:

His face looked ghastly, spangled by the veined patterns from the lampshade. The eyes were sunken and the pallor was tinged with yellow,

\footnotetext{
${ }^{1}$ For a discussion on the notion and problem of the zombie as Gothic trope see Hannah Kate's blog She-Wolf (2011): http://shewolf-manchester.blogspot.sg/2011/05/can-zombies-be-gothic.html
} 
as if he was jaundiced. He looked more dead than alive with his gaunt cheeks and thin neck. (Maniam, 1996, p. 3)

The title "Terminal" suggests the slow spread of a cancer that threatens the multicultural structure of the society, with Kok Seng imprisoned in a world of uncertainty. When the narrator states, "I've found my direction," Kok Seng replies, "You think you have. . .then everything goes to pieces" (Maniam, 1996, p. 3). He becomes a zombie unable to function in a city where the Muslim taboo against the eating of pork becomes increasingly restrictive forcing Chinese cultural food festivities to go underground:

What l'd taken to be indifference some years back had become something which came with the well-kept streets, the restricted lists of food and drink available in cafes and restaurants, the chill air that was being pumped, through concealed vents, into the streets (Maniam, 1996, p. 8)

Psychoanalytic theory suggests whatever is repressed may manifest itself in hauntings or rebellions against authority (Hogle, 2002). These cultural anxieties are voiced through Kok Seng's defiance of the prohibitive laws: "I won't let this happen!' he said. 'Can't be scraping and bowing!'. . . . I'll show you where we can eat real food!" (Maniam, 1996, pp. 9-10).

Following in the tradition of gothic narratives, the disenfranchised Kok Seng seeks the guidance of a Chinese Master steeped in the rituals of ancient practice to assert his cultural identity. The gothic world of shadows, darkness and the freeze of the airconditioned, steel-encased city take on sinister undertones as Kok Seng and his friends engage in the ritualistic slaughter of a pig, a taboo animal in Islamic tradition:

It blinked at the harsh light that fell into the ring. They must have kept the animal away from any kind of light until that day, I thought. Had farmers set up clandestine pig farms? How had they brought the animals - I heard several grunts inside the hut - to this part of the city, undetected? (Maniam, 1996, pp. 15-16)

The ritualistic killing of the pig is brutal, with the Master ordering the initiates to plunge their fists into the body of the animal and "Pull out the heart" (Maniam,1996, p. 17). As in the tradition of ritualistic worship, the blood sacrifice and eating of the heart of the pig empowers the disgruntled clan members.

The threats to identity and culture, the unsaid, or the repressed is voiced through Kok Seng's disintegration. He is a haunted spectre of the man: "I'm no more myself. Here 
in this place and time, it isn't possible to be yourself. It isn't possible, it isn't possible . .." (Maniam, 1996, p. 21). In an increasingly hostile city, he becomes a vampire-like figure existing in a funereal environment where all hope is abandoned:

I smelled a strong draft of wood-smoke. ... It came from an old-fashioned casket - banned now because it gives too much importance to the dead and takes up too much ground space - up against the wall, at the foot of his bed. The whole room wasn't a room at all; it was more a temple, with its red, electric candles and calligraphed verses plastered all over the walls. ... The lid was displaced enough to create an entrance into the coffin. (Maniam, 1996, p. 21)

As in the gothic tradition, "Terminal" suggests there is no resolution between the disintegrating self and the constraints imposed by society, indicated by Kok Seng's descent into madness and chaos.

Many of the alienated, disenfranchised characters in Maniam's short stories in Haunting the Tiger (1996) embody the characteristics which Julia Kristeva in Powers of Horror (1980) describes as abjection:

There looms within abjection, one of those violent, dark, revolts of being, directed against a threat that seems to emanate from an exorbitant outside or inside, ejected beyond the scope of the possible, the tolerable, the thinkable. It lies there, quite close, but it cannot be assimilated. (p. 1)

Like Kristeva's abject beings, Maniam's characters in Haunting the Tiger (1996) find it increasingly difficult to form a coherent identity in a destabilising word. For example, in the short story "Haunting the Tiger", Muthu's recollections on his deathbed are his inability to fully belong in a land whose customs and traditions he rejects to preserve his Indian heritage. He is haunted by dreams of returning to a time before birth:

His mind emptied itself of all that he himself had gathered through the years and left him naked, skinned. 'This is the falling out of from the skin I knew of long along.' He had experienced this just after his mother died, when he was about eight. It was not just a sense of loss his mother's death brought but a loss of the self. The person he had known himself to be suddenly died. (Maniam,1996, p.37)

Muthu's deathbed recollections may be interpreted as a desire for the imagined unity of the primordial space, which Kristeva (1982) describes as the "in-between" state before birth when the child is part of and separate from the mother. It is a state of liminality which individuals have to overcome in order to establish a coherent and 
stable identity. The womb-like environment of the jungle in Muthu's recurring dreams suggests his interrogation of his identity:

On the mindscape that lay now between life and death, confused and murky, there rose a fresh, green land. Seeds popped, transparent thin stems reached out of the ground; the surface cracked and thick tree trunks heaved themselves through the resinous soil. (Maniam, 1996, p. 38)

Muthu's regret is he never successfully negotiated the transition from being the son of immigrants to forming a cultural identity incorporating his Indian and Malaysian heritage.

This theme emerges in the metaphor of the younger Muthu's hunt for a tiger he has seen prowling in the jungle. The tiger symbolises power and control of the environment. The primordial chaos of the jungle is a redemptive space for the young Muthu with its promise of growth and integration: "The land that came to him now came before the remigration of peoples to their original countries, the great war and harsh, sun-reflecting buildings" (Maniam, 1996, p. 37). Muthu's parents believe that they can overcome their alienation by returning to the country of their birth, but Muthu realises this was never an option because his identity is enmeshed with the cultural traditions of the Malaysian society he was born in:

Of late, he has been forced into thought by his disgruntled parents: they want to return to the country from which they came. 'They can give up this land for a life they've known,' he thinks. 'But what do I have to give up? (Maniam, 1996, p. 38)

He believes he can forge a stable identity if he is able to capture the tiger. But the tiger is a mythical beast that cannot be possessed. His transitional state is symbolised through his dreams of being a chameleon:

His tapering, curled tail is hooked onto the branch of a huge tree. His eyes, encircled by lids that never close, look at the danger below but he is also excited by the leap he will have to make. His tail unclasps and as he hurtles through the changing hues of the foliage and sees the red, dark, earth rush up at him, he screams, 'I'll possess! l'll possess!' (Maniam, 1996, p. 42).

In folklore, a wise man or guide is sent by the gods to assist in the journey to an integrated self. In "Haunting the Tiger" (Maniam, 1996), the role is assigned to Zulkifli, a Malay man, who lives on the edge of the jungle. He is aware Muthu's desire to hunt 
the tiger stems from his need to control an environment that threatens annihilation. It is the same hunger Zulkifli's ancestors experienced in taming the jungle: "My forefathers had the same look in their eyes" (Maniam, 1996, p. 42). Zulkifli's attempts to mentor Muthu in the indigenous laws of the jungle fail because of a conflict in their cultural interpretations of the land. "Zulkifli has known it all: how to take Muthu into the knowledge that resides within him?" (Maniam, 1996, p. 43). Their cultural beliefs about ownership and belonging differ. Zulkifli's indigenous interpretation of the land is that the tiger and the jungle represent the story lines of his ancestors: "The tiger roamed this land before man's mind learned to remember. . . . Its stripes are everywhere" (Maniam, 1996, p. 44). Muthu believes shooting the tiger will establish his authority. Authority can never be negotiated through violence is Zulkifli's warning. Muthu is unable to make the transition into the Malay consciousness Zulkifli demands of him: "'So you brought a purpose with you?' Zulkifli says. 'And a way of thinking. How can you get into the tiger's stripes and spirit?'” (Maniam, 1996, p. 45). The dying Muthu realises that he has never successfully negotiated the transition from Other to being at home in the environment.

Their journey into the jungle in search of the tiger highlights their cultural differences. Zulkifli believes Muthu's desire to kill the tiger violates the sacred space of the tiger: "'l know what's wrong,' Zulkifli says. 'There's something foreign to the tiger's nose. He won't show himself until the smells are gone'" (Maniam, 1996, p. 45). Zulkifli's consciousness is of living in harmony with the tiger: "The clothes you wear, the thoughts you think. Where do they come from?" (Maniam,1996, p. 45). There is a moment of epiphany when Muthu enters into the Malay consciousness of being one with the tiger:

His skin begins to burn; he feels his clothes are no more there on his body. The light scars the land put on him, some months back, are opening up. He is flowing out towards the stripes, helplessly, when with a cry of anguish, he wills his consciousness into action. (Maniam, 1996, p. 46)

On his deathbed, Muthu realises it was too great a sacrifice to denounce his Indian cultural heritage: "Afraid I would fall into a dark, deep hole . . . Running away from those stripes. Too deep, too invisible. How to enter so deep in? Give up what I was . . . I was nothing. Am nothing. .." (Maniam, 1996, p. 46). The abject is voiced in his regret that he allowed fear and negativity to overcome what could have been: "This is the dying. Having not lived, this is the dying..." (Maniam, 1996, p. p. 46). Cultural identity is formed by letting go of cultural traditions that restrict growth, while maintaining integrity and trust. Muthu's regret is he never successfully negotiated the integration into mainstream society. 
Shirley Lim's stories in Life's Mysteries: The Best of Shirley Lim (1995) suggest a struggle with overcoming the patriarchal structures of customs and traditions that constrain women. The gothic motifs of the journey into the underworld, of darkness and shadows express the metaphorical exile of the disempowered and disenfranchised female protagonists. The narrator in each story has a different ethnic identity, emphasising their sense of isolation. The motifs are of hunger, disempowerment, marginalisation, and of the injustices and inequalities that societies ignore or pretend do not occur. For example, "Journey" (Lim, 1995) incorporates the mythological journey into the underworld, darkness and death. The dreams of a woman recalling a dark childhood, of hunger, poverty and of the demise of innocence intensify the surreal element. It is a world of dream and nightmare:

Last night, she had dreamt she was shut away in a subterranean world; she had wandered in labyrinths of a thick brown claustrophobia. So dense was the air that her ears felt clogged with cotton-wool, and her feet trod slippery over ground strewn with skulls. (Lim, 1995, p. 13)

In the liminal world between the dream and waking state, the narrator remembers the child's journey on a bus, and the fear and the uncertainty of where she was to go or what she was meant to do. The child remembers vividly her outsider marginalised status as the bus laboriously trundles through the suburbs of curtained houses "sitting under fat protective trees, hiding behind fences and shut gates. . . . In these houses were whole families unaware of her standing hungry, out in the dark." (Lim, 1995, p. 14-15)

The journey signifies her transition from innocence to experience, when she enters the household of the man her mother had instructed her to see, a world of drugs and corruption opens up:

An altar faced the open door, unlighted candles placed before the household god, an inscrutable figure who sat and watched the domestic goings-on, always to be placated, never to be pleased, awful Lord of the destiny of furniture, food and family. A gold dragon paced along the sketch of the wall. Its predatory jaws yawned in eternal pursuit . . . (Lim, 1995, 15)

The sacred and the profane are presented through the indifference of the gods to the transaction between the man and the girl and the discomfort she feels in his presence: "He took the money she gave him disinterestedly, yet she thought his eyes rifled her clothes and she was glad to leave" (Lim, 1995, p. 16). It is only later that she realises the magnitude of giving the man the money for a parcel her mother had requested. There is a hint of potent magic in the parcel: "The little parcel wrapped roughly in brown 
paper and tied with a rubber band, crackled under the pressure of her fingers. If felt of dry leaves and twigs which crumbled even as she held it gently" (Lim, 1995, p. 16).

The parcel and the child's memories of her mother's weariness from the burden of too many pregnancies are inextricably linked. The dark tale unfolds like a slow bleeding wound, culminating in the mother aborting the baby whom she cannot afford to feed or love, while her husband slumbers in the next room:

The blood seemed to gush from some fatal injury to the woman's flesh, this woman now unrecognizable as her mother, who groaned and clutched her side, writhing. She was repulsed by the pain and blood. They lay beyond her experience, yet some instinctive sympathy, a habit of sex, made her arms and legs move. (Lim,1995, p. 17)

Their roles are reversed, with the child nurturing the mother: "She shuddered in the cold air, shuddered at the shock of cold water, and, shuddering as she washed, the girl cried" (Lim, 1995, p.18). It is only then the child realises the significance of the journey and her transition into the world of experience and suffering.

The gothic themes of dream and nightmare continue in Lim's short story "Two Dreams" (1996). Martha lives in New York, but her dreams are of her birthplace in Malaysia, and of a nostalgia for the embryonic warm, salty sea of her childhood: "She was sitting on the carrier of her brother's bicycle while he cycled fast on the beach" (Lim, 1995, p. 38). Her loneliness is exacerbated when she wakes to the cold of a New York winter. Her nostalgia is banished when she returns to Malaysia. She attends a political rally, where she witnesses a uniformed guard beating a street-child for venturing too close to the Prime Minister's cordoned area:

[T] he guard, a commanding person in jungle-green uniform and a gun in his belt clinched tight around his burly waist. . . . turned around, raised his stick and swung it twice, hitting the handsome dark head once and the bare shoulder once. The boy dropped silently to the ground, then he scrambled frantically through the legs of strangers until, at a safe distance from the guard who was glowering and gesturing fiercely still, he whimpered, put his hand to his head, and cried with pain. (Lim, 1995, pp. 42-43)

The blows directed at the "dark head and the bare shoulder" of the boy, his fear, and the guard's violence towards the street-child undermines the Prime Minister's political speech about equality and justice for all citizens. The incident haunts her dreams of "war and fighting" and police beating students (Lim, 1995, p. 43). Martha chooses to 
return to the cold of a New York winter, remembering the inequities that had made her leave her birthplace.

Alienation and disengagement with the patriarchal structures which confine women whether set in New York or the metropolises of tropical Asia - resonate in Life's Mysteries (Lim, 1995). Urban metaphors of power and violence merge with that of family, rituals and relationships. In the short story "A Pot of Rice" (Lim, 1995), Su Yu is a teacher who commutes between Brooklyn and Queens, reflecting on the tediousness of her two-hour journey, often in cold unrelenting weather, in overcrowded subways where people are imprisoned in their own world. Memory and home are resonating themes. In the cold confined space of the subway, she overcomes her sense of isolation by contemplating the meal she will cook with cloves, chillies and spices and the warm steam from the rice which will "spark the brown lonely kitchen with fiery scents" (Lim, 1995, p. 56). Food symbolises Su Yu's connections with her heritage and identity as well as the dislocation she experiences in New York.

The migrant's longing for home in a new environment is given voice through Su Yu's despair at the loneliness she experiences when her brother informs her of her father's passing - two weeks after the event. "With her father's death there was no longer any reason to leave the city from whose harbour the statue of Liberty seemed to gaze across the oceans to Singapore as if towards a giant Chinatown ghetto" (Lim, 1995, pp. 56-57). Her liminality in New York is voiced through memories of the Chinese rituals performed at her grandfather's death when she was a child, rituals which provided solace and a strong sense of community:

Young men carried banners of bright-coloured cloth emblazoned with laments and old men pushed carts loaded with water pots for the family who stumbled in the heat behind the truck. Her black dress had just come from the dyer's and smelled sweetly of faded flowers. She wore a hood of gunny sack and grass sandals tied around her shoes. Everywhere women were crying and waving their arms helplessly. (Lim, 1995, pp. 5758)

She feels alienated from mainstream society because the rituals have no meaning in New York: "This is the time of prayers for father, she remembered. Her mother would have the altar freshly dusted and a clean red prayer cloth hung in the front" (Lim, 1995, p. 58).

The ceremony of mourning she emulates in memory of her dead father only serves to highlight the emptiness she experiences: 
A blurred machine-made snapshot of Su's father was propped before a candlestick which stood behind a cereal bowl filled with cooked rice and a plate holding a whole boiled chicken. The rice was ashy-was it from the candleflame or from the mould in the air? The chicken's boiled skin was discoloured, dotted with pink and black feather marks which showed garishly under the fluorescent light. (Lim,1995, p. 58)

The glare of the fluorescent light, the makeshift altar and the "ashy" rice intensify Su Yu's loneliness and the insignificance of rituals when there is no family or community to connect her to her cultural heritage.

The recurring motifs in Lim's Life's Mysteries, Maniam's Haunting the Tiger, and Yahp's The Crocodile Fury are of alienated characters haunted by a historical past striving to establish a coherent identity in a postcolonial world of changing spiritual and cultural beliefs. These authors use gothic narrative to articulate the lived experience of diaspora. The gothic elements in these fictions of an unreal world and alienated characters probing religious, social and cultural anxieties suggest identity and being are ongoing processes; as such, the characters' identities are informed by their ability to adapt their religious and cultural practices to the cities they live in. Most importantly, Yahp, Maniam, and Lim manipulate the haunted spaces of the gothic to articulate their philosophical and social concerns of tropical societies negotiating the ambivalence of postcolonial subjectivity.

\section{References}

Couteur, P. L. (2015). Slipping off the sealskin: Gender, species, and fictive kinship in selkie folktales. Gender Forum, (55), 1. Retrieved from https://search-proquestcom.elibrary.jcu.edu.au/docview/1748547384?accountid=16285

Hogle, J. (Ed.). (2002). The Cambridge companion to gothic fiction. Cambridge, England: Cambridge University Press.

Kristeva, J. (1982). Powers of horror: An essay on abjection. Trans. L. S. Roudiez. New York, NY: Columbia University Press.

Lim, S. (1995). A pot of rice. In Life's mysteries: The best of Shirley Lim (pp.54-59). Singapore: Times Book International.

Lim, S. (1995). Journey. In Life's mysteries: The best of Shirley Lim (pp.13-18). Singapore: Times Book International.

Lim, S. (1995). Two dreams. In Life's mysteries: The best of Shirley Lim (pp. 38-44). Singapore: Times Book International.

Maniam, K.S. (1996). Haunting the tiger. In Haunting the tiger: Contemporary stories from Malaysia (pp. 37-46). London, England: Skoob Books Publishing.

Maniam, K.S. (1996). Terminal. In Haunting the tiger: Contemporary stories from Malaysia (pp. 1-21). London, England: Skoob Books Publishing 
$\mathrm{Ng}, \mathrm{A}$. H-S. (2006). Malaysian gothic: The motif of haunting in K.S. Maniam's haunting the tiger and Shirley Lim's haunting. Mosaic, 39 (2), 75-87.

Yahp, B. (1992) The crocodile fury. (1992). Pymble, NSW (Australia): Angus \& Robertson. 